に分けて考えると前者のばらつきによるものであるこ とから， $t_{d_{2}}$ のひん度分布曲線がボルッマンの統計的 手法により求められている.

[神山 新一]

\subsection{5}

[184]層流における軸対称旋回噴流 [I. Wygnanski, Phys. Fluids, 1970-10, Vol. 13, No. 10, p. 2455 2460, 図 13]層流の旋回噴流に対する完全 な理論解析はいまだ得られていないが，本報告は旋回 の強さに制限がある従来の解析をさらに一歩進めて, 非圧縮軸対象流れの仮定のもとにナビエ・ストークス 方程式の相似厳密解を求内，旋回強さの広い範囲にわ たって噴流に対する旋回成分の影響を吟味している. 数值計算の結果によれば，旋回噴流はたがいに密接に 関連している運動量と角運動量ならびに壁面境界条件 に支配され（遠心力と压力こう配の平衡による），運 動量が十分大きくさらに角運動量が十分小さいときの み壁の影響を受けない（運動量が小さいと圧力の項は 無視できず，いわゆる従来行なわ机ている境界層近似 は妥当でない)。 また旋回の存在は各速度成分にかな りの影響を与え, 特に軸速度の半径方向に対する分布 は極大值を持った曲線になることなどを理論的に明ら かにしている. しかしこれらの解析結果が乱流に対し てどのような関連を持つかは不明であり今後の課題と いえよう。

[橋本 弘之]

\subsection{2 : 532.55}

[185]曲管內の流れに関する実験と計算 [M. Rowe, J. Fluid Mech., 1970-10, Vol. 43, No. 4, p. 771 783, 図 6] 3 種類の曲管内の流れの発達およ び下流直管内における流扎の回復に関して㬰験を行な い，これを電子計算機による計算結果と比較してい る. 実験はレイノルズ数が $2.36 \times 10^{5}$ にて行ない，入 口からの曲がり角 $\theta$ の種々の值について，管断面の全 圧分布と流れの管軸に対する傾きを，おのおのピトー 管とヨーメータによって測定している. 入口 $(\theta=0)$ では十分発達した乱流の速度分布を与えている．まず $180^{\circ}$ 曲管の場合には，二次流れの強さは $\theta=30^{\circ}$ のと き最大に達し, その後減少して $\theta=90^{\circ}$ で十分発達す る. 計算結果は $\theta=75^{\circ}$ まで定性的に一致する。曲管 を出たのち流れが回復するためには, $61 d$ ( $d$ : 管内径) 以上必要である. $45^{\circ} \sim 45^{\circ} \mathrm{S}$ 宇曲管では $\theta=45^{\circ}$ の面 を通過すると，流れの中央に低圧部が張り出してく る.しかしS 字部を出るとこの低圧部は早急に消隇す るので, 流れはわずか $13 d$ 下流でほぼ回復する. $30^{\circ} \sim$ $30^{\circ} \mathrm{S}$ 字曲管についても実験している.この場合にも 計算結果はよく一致する. 〔南部 健一]

\section{$532.543: 532.58$}

〔186]2 平行円板間の定常および非定常旋回流の速 度プロフィル [F. Bien and S.S. Penner, Phys. Fluids, 1970-7, Vol. 13, No. 7, p. 1665 1671, 図 9, 表 1] レーザ光によるドプラーシフトを利用す ることにより,一方の円板が角速度 $\omega$ で回転し, 他 方の円板が静止している 2 平行円板 (直径, $2 a=7 \mathrm{~cm}$ と $10.5 \mathrm{~cm}$, 間隔, $h=0.67 \mathrm{~cm}$ 亡 $1.35 \mathrm{~cm}$ で側壁あ り）間の定常および非定常旋回流の周速度分布がレイ ノルズ数 $R_{e}\left(=\omega h^{2} / \nu\right)$ が小 $(\approx 5)$ および大 $(\approx 1000)$ の場合に対して測定された.その結果, まず側壁から十 分離れた半径位置での定常流の速度分布は円板半径 $a$
を無限大とした場合の理論解とよく一致すること,つ ぎに，回転円板が突然停止する場合および静止状態か ら突然角速度 $\omega$ で回転する場合の非定常問題では $R_{e} \cong 5$ の場合には $a=\infty$ の線形理論による解(1)とよく 一致するが $R_{e} \cong 1000$ の場合には線形理論解はもはや 適用できないことが示されている.

さらに, $R_{e} \cong 1000$ での急加速の場合, 一定速度に 発達するまでの時間 $t$ は側壁から測定点までの距離を 表わすパラメータ $\alpha=(a-r) / a$ に強く依存する $(\alpha \rightarrow$

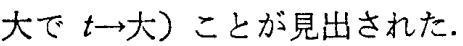

(1) Pearson, C.E., J. Fluid Mech., 21-4 (1965-4), 623. [神山 新一]

\section{$532.528: 678$}

※[187] ポリマの添加による高速水流中のキャビテー ション抑制効果 [A.T. Ellis, J.G. Waugh, and R.Y. Ting, Trans. ASME, Ser. D, 1970-9, Vol. 92, No. 3 , p. 459 466, 図 7, 表 2] 数 $\mathrm{ppm} \sim$ 数百 $\mathrm{ppm}$ 程度のある種の高分子溶液（ポリマ溶液）は通常の水 と比較して乱流摩擦抵抗值が著しく減少する（トムズ 効果）ほか，種々のニュートン流体とは異なる流動現 象を示すことはよく知られているが，本論文ではキャ ビテーションの初生に及ぼす添加ポリマの影響を調ベ るために行なわれた種々の濃度の高分子溶液(Polyox, guar gum および algae) による半球形頭部を持つ円 筒形物体（直径 $D=1 / 4$ in と $1 / 2$ in）まわりの流れの キャビテーション試験結果が報告されている.

実験は高分子溶液の変質の影響を避けるために blow-down tunnel (加圧タンクにより静止溶液を加 速する）を用いて行ない，キャビテーションの初生は 直径が 0.1 in の $\mathrm{He}-\mathrm{Ne}$ ガスレーザ光のキャビテー ションによる散乱を光電管で捕える方法で検出してい る. 実験結果より高分子溶液での初生キャビテーショ ン係数の值は通常の水の場合よりかなり低い值をとる ことが明らかにされているが，まだその抑制効果の原 因を解明するまでにはいたっていない。

\section{[神山 新一]}

\section{$538.3: 532.5$}

[188]ダクト内の MHD 流扎の問題に対する変分 原理の応用 [N.C. Wenger, J. Fluid Mech., 19708, Vol. 43, No. 1, p. 211 224, 図 5] 任意の断 面形状を有するダクト内の MHD 流えの問題を変方原 理を応用して簡単に，しかも精度よく解く試みは最初 谷(1)により行なわれ，数值計算例として長方形断面を 有するダクトの管壁が絶縁体の場合および絶縁体と完 全導体とからなる場合につき誘起磁場の強さおよび流 速分布に対する解が与えられている。

本報告では，この方法を流速および電圧分布に対す る解を与えるようにして用いることにより壁面が絶縁 体と任意 (有限) の電気伝遒率を有する遒電体とから なる場合に適用できるようにした．さらに，MHD 流 れのエネルギ平衡条件を検討することにより，はん関 数 $F$ の停留值は压力こう配により流体に加えられる 動力と外部回路に取出される電気エネルギの差に比例 すること，したがって，開放回路（外部回路を流れる 電流が零）の場合にはダクト内の平均流速に比例する ことが示されている.

(1) Tani, I., J. Aerospace Sci., 29 (1962), 297.

\section{[神山 新一]}

